\title{
The Role of Hr Managers During Crisis Time - Covid-19 Perspective
}

\author{
Naiymunnisa Begum, Shaik Abdul Mazeed
}

\begin{abstract}
COVID-19 pandemic has disturbed organizations and made HR personnel to think differently by considering new normal norms like social distancing, new work conditions that they may never have envisioned. To stop the spread of the coronavirus, organizations have changed to a Work from Home Model (WFHM), Remote Connections (RC) at a rate and scale, monitored and controlled by email and video conferencing. Sum and substance, HR Managers role has become more crucial and need to accomplish troublesome work under these unprecedented conditions. HR is worried about employee's wellbeing and prosperity during the pandemic; they are under the strain of handling the deskwork and giving comfort to the large number of labourers simultaneously. HR has consistently been the front liner for workers and the HR's job in observing and keeping up has gotten significantly. Traditional HR is being supplanted with a comprehensive methodology utilizing trend setting innovations and being human driven too. HR managers are literally doing war with the difficulties of reclassifying their techniques on administration, ability, assorted variety while assessing their operational adequacy. The world stands up to different emergencies and COVID-19 being the greatest one right now which has hit the entire world and its economy. In this scenario, this research paper emphasised on role and challenges of $H R$ during the pandemic.
\end{abstract}

Key Words: COVID-19, Organizations, HR Personnel, Work from Home (WFM), Administration, Remote Connections (RC)

\section{I.INTRODUCTION}

$\mathrm{R}$ emarkable changes brought by COVID-19 have maintained associations around the globe to animate the advancement to automated business measures. HRM is at the centre of these progressions helping organizations with investigating the hazy present and unforeseeable future.

HRM needs to regulate people in associations during the crisis to engage business congruity and assurance harmony between serious and fun times. Since the future will bring more versatile, professional, mechanized working norms, the changes in methodologies, measures, workspaces, composed exertion structures, and labourer wellbeing are of dynamically critical importance.The new changes brought by the general pandemic (Covid-19) have constrained relationship to stimulate the advancement to modernized undertakings. This move has compelled HRM to investigate laborers in this excellent situation.

Manuscript received on February 10, 2021.

Revised Manuscript received on February 17, 2021.

Manuscript published on February 28, 2021

* Correspondence Authors

Dr. Naiymunnisa Begum*, Associate Professor, Amjad Ali Khan College of Business Administration, Hyderabad-500034, Telangana.

Shaik Abdul Mazeed, Research Scholar (Part-Time), Yogi Vemana University, YSR Kadapa-516005, Email ID: mazeed22@gmail.com

(C) The Authors. Published by Blue Eyes Intelligence Engineering and Sciences Publication (BEIESP). This is an open access article under the CC BY-NC-ND license (http://creativecommons.org/licenses/by-nc-nd/4.0/)
HRM has a huge undertaking to do from one perspective to help workers in using automated stages to get to their positions, and afterward again to help organizations in their undertakings to continue with business measures. In the high-level climate, representatives need to overhaul their understanding or get new capacities.

This investigation is constrained by the effect of the new frightening crisis on associations and business movement. The purpose of this investigation is to recognize the movements that occurred in the associations in India as a response to the crisis. Therefore, the expert talk with the method was used. To investigate the advancement to the distance, accelerating of digitalization especially in the Indian associations, and their impact on the work-life harmony of agents, the investigation questions were arranged in a liberal way. The paper discusses the challenges HRM confronting due to the current crisis with respect to far off working and recognizes the proposals the pandemic has on HR. The expert meetings coordinated in India show that HRM should consider ways to deal with develop new plans for crossbreed working models as a response to the current pandemic crisis.

\section{II.REVIEW OF LITERATURE}

Sheppard (2020): The Covid-19 has increased advanced change for organizations, and numerous specialists around the globe need to have essential abilities to utilize innovations to play out their positions distantly. The advanced advances empower virtual work just as to computerize assignments and decide. The pandemic has made it noticeable that the most requested abilities for the workers are computerized, yet in addition synergistic.

Carnevale and Hatta (2020): Any issues occurring in the interconnected world support associations of any size to react and adjust to the change, just as deal with their workers appropriately. As of late, the Covid-19 pandemic has formed remarkable requesting conditions for human asset the executives. HR chiefs need to assist their representatives to deal with the fast changes in both the working environment and the general public. Besides, Covid-19 will affect significantly on the work, and can cause vocation stun for individuals.

Akerman's, Richardson, and Kramer (2020): HRM needs currently to manage the expanding pressure of their labour force brought about by distant working when work and family limits have obscured.

Narayana's, Heber, and Liang (2020): The new overview of Chinese organizations indicated that they contribute assets instead of safeguard assets, in reinforcing their serious capacity.

Published By:

Blue Eyes Intelligence Engineering

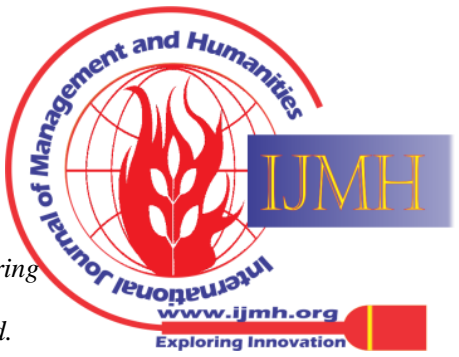

\& Sciences Publication 
It is additionally significant that business coherence, worker prosperity, and client direction are viewed as the fundamental difficulties. In addition, as new advances increment adaptability and permit the labour force to work distantly, HR the board needs to make proper approaches and execution frameworks to guarantee that representatives satisfy guidelines, and yet take out the negative impacts of computerized working specifically with respect the social cooperation.

Paisley and Colleagues (2020): Indicate that albeit far off work has numerous preferences, representatives experience "blend of business and home life", which causes inconveniences for the two administrators and laborers regarding long haul prosperity. It is significant that prosperity has sway on inspiration and execution results of representatives. The pandemic has focused the physiological and psychological wellness of individuals in the association as needs.

Spence (2020): Since numerous representatives will be more joyful to re-visitation of their workplaces while others incline toward keep working distantly, organizations revaluating the working environments should mull over these distinctions. The examination dependent on Workplace Analytics at Microsoft uncovered that workdays delayed as the representatives telecommuting endorsed into work before and closed down later as they appointed time meanwhile for private matters. Despite the fact that season of gatherings online has diminished to 30 minutes, administrators needed to assist representatives with organizing work and decrease potential negative impacts brought about by the shared space of work and home. In this way, HRM should assist organizations with changing their business measures into the advanced space by overhauling worker abilities, make association culture for flexibility to digitalization, and keeping work-life equilibrium to keep up representative wellbeing, inspiration, and proficiency.

\section{III.OBJECTIVES AND METHODOLOGY}

Objective-1: Why and how did the Covid-19 pandemic influence Human Resource Management by and large, and specifically in the Indian organizations?

Objective-2: Why Remote Working can be a satisfactory reaction to the pandemic emergency and how HRM can help organizations in computerized change?

Objective-3: How did HRM react to the emergency in India and how they make conditions for versatility of workers to the new reality?

\section{IV.ANALYSIS AND INTERPRETATION}

At this phase of the examination, the gathered information through the master meet were deciphered and dissected with the methodology of subjective substance investigation. The eye-to-eye master interviews were done utilizing the online video stage Zoom. The profundity meets with an individual master took somewhere in the range of 20 and 30 minutes. The meeting was prescheduled. The specialists were approached to permit video-recording in Zoom to record it later. They were guaranteed that their own information will be ensured, hence their characters stayed classified just as won't be accessible for any outsiders. The semi-organized meeting followed a comparative blueprint that permitted to think about information, and to keep the meeting inside the theme limits; all inquiries were open. Toward the finish of the meeting, the last inquiry was about their extra remarks or perspectives they figured it very well may be imperative to the exploration. The inquiries depended on the current writing, and depended on the master answers to suggest extra conversation starters. The inquiries were open-finished and thorough answers were normal. In general, the meeting rule comprised of 9 inquiries covering the 6 fundamental subjects. The specialists were gotten some information about the significant modifications in associations and with HR the executives, which occurred because of the pandemic, what precisely was the organization's reaction to the abrupt changes, and whether any open doors are considered for Indian organizations. Altogether, 33 specialists were welcome to the meeting for this exploration, and 10 of them were really met. Specialists were selected through the expert contacts of the analyst. At first, we reached them by means of Email clarifying the reason for the exploration and sending general inquiries questions. The experience and understanding of the specialists permit gathering essential information from different foundations and encounters to examine the effect of the emergency. They are specialists in the field of HRM, and the data they gave is a genuine impression of the present status here. They come from different associations going from counselling organizations to preparing focuses to colleges. Their working involvement with HR counselling, preparing and research field ranges somewhere in the range of 9 and 25 years.

\section{V.RESULTS AND DISCUSSION}

Remote Working in Pandemic Crisis: The pandemic lockdown constrained various challenges to the associations, HR Managers, and workers. Similarly, central needs and idiocy have been represented a large part of the time with respect to business soundness. As opposed to quickly acclimating to the new reality and beginning exercises under the pandemic conditions, the associations needed to shut down, so they started believing that the pandemic will pass. "I don't see that associations have any organized method to manage to get the hang of living and working with the disease". Besides, corporate brand and legitimate culture are under request, while the organization has less inclusion with the crisis the board. Further, they need to consider versatility and digitalization when delegates began working indirectly. As communicated by the experts may be the most concerning issue was the questionable and clashing rules as per the nonattendance of correspondence with the authoritative associations. "Right when rules change constantly and there is no prompt contact with the regulators, the perils of driving fines on associations increase if an association doesn't meet each piece of the establishment necessities because of its vulnerability and likelihood of various understandings". Regarding delegates, the experts ensure that their pressing factors, fear, and anxiety extended. They by and by the need to conform to the new reality with automated cycles and removed working, and in this way upgrade their aptitudes in online gadgets. Moreover, the workforce needs to manage joblessness or pay diminishes due to the declines achieved by the pandemic.

Blue Eyes Intelligence Engineering 
The respondents acknowledge that HRM finishes an unequivocal commitment to associations' flourishing and dismissals, turnover, and regulating alerts inside the affiliation. Additionally, new prosperity rules ought to be interpreted for association and specialist points. The experts say that some Indian associations have recently familiar with a work prosperity counsel to help the affiliation and their workforce to conform to the security rules.

In addition, the harmony between serious and fun times ought to be in a like manner tended to as most delegates were working from home where the space among work and individual life may not exist causing growing pressing factor. With respect to inaccessible work, the experts notice that a couple of associations have quite recently had a versatile working schedule especially those in the IT industry or guiding business. In this manner, their agents have changed successfully and for the most part easy to work from home. What's more, various delegates should be allowed to continue to chip away at the web after the postpandemic time period. As communicated by experts in the gathering gatherings, Indian affiliations and HR systems were not set up to work remotely neither precisely nor mentally. Also, the organization of various associations has required inclusion with supervising pressure and in change the board. Another key test the experts highlighted is simply the limit of HR specialists to direct self-administering, result-arranged, and indirectly. Effectively, various cycles and works have been done on paper, and Management was translated as control and checking of agents. During the distant working conditions, those old procedures have been tended to, and requirements towards new philosophy emerged. Nonetheless, neither HRM nor HR specialists nor delegates are ready for making and introducing novel organizational structures. "We live during a period of manmade thinking and how to exist without advancement. This pushes a person towards self-progression".

Effect of Remote Working on Work-life Balance from the Perspective of HRM

The representatives are pounding endlessly and zeroed in on their situations for around 7-8 hours, while working from home incorporates huge interferences, for instance, kid care, family tasks, and consequently, laborers need to play out the designated endeavours around night time. Various Indian started and when they finished the work i.e., where was the line among work and home. "The area where they refreshed, the house, is mixed in with the work associations". At the same time, if various people from the family moreover worked remotely and the assessment has been done online additionally, there has been a lot of mental squeezing variables and pressing factor. In this way, HRM should help the workforce with getting sorted out the space and schedules for working indirectly mulling over the individual differences or conditions to keep up equilibrium between fun and serious stuff. Though chipping away at the web can be beneficial for associations, its most noteworthy shortcoming is a nonappearance of socialization. The respondents saw that there should be a room left when changing to the distant mode to mastermind get-togethers in working environments occasionally. This will incite a more pleasing viewpoint and enthusiastic wellbeing achieving laborers' success. All the while, HRM has overseen delegates have complained that they didn't grasp when they

improved motivation and effectiveness of the staff. In the appraisal of the trained professionals, whether or not a couple of positions remain totally remotely, there ought to even now be coordinated very close get-togethers now and again to conquer disengagement and support social relations for laborers.

Handling Covid-19 Crisis from perspective of HRM Digital Transformation: All through the pandemic crisis, HRM has taken up the organization and more prominent commitment at various affiliations zeroing in their resources on handling issues. The respondents imparted their viewpoints on how Indian associations have dealt with the pandemic crisis from an HRM perspective. Digitalization was seen as a gadget to make business practices possible during the pandemic. Plus, the meaning of digitalization has extended during the crisis time span. In this way, far away organization of associations has been allowed, and the capacity of electronic business has expanded. The pandemic animated the digitalization of business gauges in like manner in Indian associations. It isn't any more outlandish for bosses to work from home. Taking everything into account, digitalization in India isn't in norm as in the wake of continuing various associations returned to the standard detached strategy for exercises. While some Indian associations see the online stages just as a change framework to get back to their normal reality, others used the whole capacity of online advancements during the crisis to hold a relationship with workers through online gathering get-togethers, and even to join new agents even more quickly. HRM should help associations with making decisions whether a couple of positions will be moved generally or absolutely remotely, through various positions ought to be recognized which can't be performed from home. The experts underscore that the pandemic situation and security rules enliven the route toward working remotely joined with change using electronic redirects in Indian associations. Occupations will be on a very basic level changed. Likewise, both the associations and the workforce need to secure more inventive data and experience, make progressed capacities, similarly as be versatile, more adaptable to changes, and prepare for future weaknesses.

Table-1: Impact of COVID-19 Pandemic on HRM

\begin{tabular}{|c|c|c|c|c|}
\hline $\begin{array}{l}\text { Digital } \\
\text { Transmissi } \\
\text { on }\end{array}$ & $\begin{array}{l}\text { Remote } \\
\text { Working }\end{array}$ & Challenges & $\begin{array}{l}\text { Impact on } \\
\text { Indian } \\
\text { Organizations } \\
\end{array}$ & HR Role \\
\hline $\begin{array}{l}\text { Digital } \\
\text { Platforms } \\
\text { Artificial } \\
\text { Intelligence } \\
\text { Robotics } \\
\text { Augmented } \\
\text { Reality }\end{array}$ & $\begin{array}{l}\text { Collaborati } \\
\text { on Skills } \\
\text { Technologi } \\
\text { cal Skills } \\
\text { Communic } \\
\text { ation } \\
\text { Socializati } \\
\text { on } \\
\text { Motivation } \\
\text { Efficiency }\end{array}$ & $\begin{array}{l}\text { Business } \\
\text { Continuity } \\
\text { Customer } \\
\text { Orientation } \\
\text { Employee } \\
\text { Wellbeing } \\
\text { Job } \\
\text { Characterist } \\
\text { ics } \\
\text { Job } \\
\text { Satisfaction } \\
\text { Digital } \\
\text { Skills } \\
\text { Isolation }\end{array}$ & $\begin{array}{l}\text { Business } \\
\text { Shutdown } \\
\text { Low Revenue } \\
\text { Comply with } \\
\text { Regulations } \\
\text { Lack of } \\
\text { Knowledge in } \\
\text { Crisis } \\
\text { Management } \\
\text { Lack of } \\
\text { Remote } \\
\text { Experience } \\
\text { Lack of } \\
\text { Technology } \\
\text { Lack of } \\
\text { Flexibility and } \\
\text { Adaptability }\end{array}$ & $\begin{array}{l}\text { New HR } \\
\text { Polices } \\
\text { Upgrade } \\
\text { Employee } \\
\text { Skills } \\
\text { Online } \\
\text { Performan } \\
\text { ce } \\
\text { Manageme } \\
\text { nt } \\
\text { Work Life } \\
\text { Balance } \\
\text { Facilitate } \\
\text { Digitalizati } \\
\text { on }\end{array}$ \\
\hline
\end{tabular}

\section{VI.CONCLUSION}


In this paper, the thought was an immediate aftereffect of the Covid-19 emergency on HRM like digitalization and it's going with harmony among fun and genuine stuff issues. Enthusiastic master talk with the methodology was applied for this examination as the primary bearing to even more plausible shape the burdens accomplished by the current pandemic emergency. The motivation behind the evaluation was to reveal the different levelled choices and to find a few solutions concerning crafted by HRM during the emergency. The specialists' decisions were set up in their arrangement and individual experience. During the evaluation, associations were made trailed by information understandings, conversations of disclosures, and terminations. The specialists have assessed the comparative models experienced during the emergency circumstance concerning human asset the board and effect on specialist thriving. The bantered with specialists besides saw that work fundamentals burned-through the private space that has been actually set something aside for particular life. Different experts in India played out their circumstances around the evening. They have been meandering to unplug from work and release up. As requirements are, dispose of online parties on unequivocal days will address this issue. As removed working has risen during the lockdown, it is depended upon to change the new working life. To change rapidly to changes, improving correspondence is of basic significance. The HR supervisors don't have to screen enthusiastically the specialists work works on during far away from filling in as they can perform assignments energetically with the responsibility. The labour force has stretched out the need to shield flourishing, and workers' thriving and security are besides unequivocal for the relationship to make different levelled attributes and extended length brands. Thusly, considering specialists' congruity among genuine and fun occasions during digitalization measures is urgent. Given a few specialists like to continue to telecommute while others attempt to reappearance of workspaces, the new HR approach ought to permit the labour force to pick the work mode. HR supervisor's zones requested to make structures correspondingly. Additionally, the procedure for development, work trips, and corporate occasions need in like way to be changed. Today, the essential target affiliations set in relationship with $\mathrm{HR}$ the board are to collected a crossover model to permit the labour force to keep on working distantly, to re-examine authoritative culture correspondingly, to enlist far away delegates, and make modernized office spaces.

\section{REFERENCES}

1. GCCI. (2020). COVID-19 Survey - Business Needs Assessment. Indian Chamber of Commerce and Industry (GCCI.GE). Tbilisi: Indian Chamber of Commerce and Industry.

2. ILO. (2020). International Labour Organization. Retrieved July 30, 2020, from COVID-19 Causes Devastating Losses in Working Hours and Employment.

3. Lyadova, N. M., \& Serta ova, E. A. (2015). The Method of Expert Interview as an Effective Research Procedure of Studying the Indigenous Peoples of the North. Journal of Siberian Federal University. Humanities \& Social Sciences, 1(8), 114-129.

4. Megrel, I., Edelman, N., \& Hauge, N. (2019). Defining digital transformation: Results from expert interviews. Government Information Quarterly, 36(4), 101385.

5. Narayana's, D., Heber, V., \& Liang, L. (2020, June 5). Lessons from Chinese Companies' Response to Covid-19. Retrieved July 28, 2020, from Harvard Business Review: https://hbr.org/2020/06/lessonsfrom-chinese-companies-response-to-covid-19
6. Parry, E., \& Battista, V. (2019). The impact of emerging technologies on work: a review of the evidence and implications for the human resource function [version 1; peer review: 2 approved, 1 approved with reservations]. Emerald Open Research, 1(5)

7. Paisley, M. C., Hochstein, B., Britton, B. P., Srivastava, R. V., \& Stewart, G. T. (2020). Can't leave it at home? The effects of personal stress on burnout and $\mathrm{T}$ salesperson performance. Journal of Business Research (117), 58-70. https://doi.org/10.1016/j.jbusres.2020.05.014.

8. PwC India. (2020). Indian Business in the face of the Covid-19 Pandemic. Tbilisi: PwC in Cooperation with Investors Council.

9. Sheppard, B. (2020, May 18). A guide to thriving in the post-COVID19 workplace. Retrieved July 30, 2020, from World Economic Forum: https://www.weforum.org/agenda/2020/05/workers-thrivecovid-19-skills/

10. Silverman, D. (2000). Doing qualitative research: A practical handbook. Thousand Oaks, CS: Sage.

11. Spence, P. (2020, July 26). How COVID-19 reshapes the mental health needs of workers. Retrieved August 2020, from Ernst \& Young

12. Van der Lippe, T., \& Liponym, Z. (2019). Co-workers working from home and individual and team performance. New Technology, Work and Employment, 35(1), 60-79.

13. World Economic Forum. (2018). The Future of Jobs Report 2018. Colony/Geneva: Centre for the New Economy and Society.

\section{AUTHORS PROFILE}

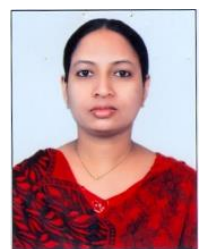

Dr. Naiymunnisa Begum, Associate Professor, Amjad Ali Khan College of Business Administration. She is a well reputed academician with over 23 years of teaching experience in various Osmania University affiliated colleges and B-schools also have two years of industry experience.

She holds dual PG degree MA in English language teaching from Osmania University and MBA from Annamalai University and later completed her PhD from JNTU Anantapur. She published research articles in various national and international journals and also Scopus Indexed journals. Apart from teaching she is the chairperson of language lab, committee member of placement cell, committee member of innovation cell, coordinator for external examinations and so on.

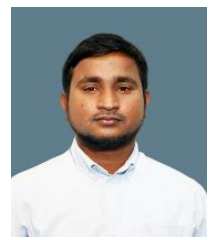

Shaik Abdul Mazeed, MBA, APSET, (Ph.D.), Working as an Assistant Professor in Dr. B. R. Ambedkar Institute of Management and Technology, Baghlingampally, Hyderabad. He has a decade experience in Teaching, Research and Industry. Presently he is pursuing his $\mathrm{Ph}$. D from Yogi Vemana University, YSR Kadapa, Andhra Pradesh.

He holds MBA degree with a dual specialization in Human Resources Management and Finance from Osmania University. His areas of interests are Operations, Finance and HR. He has more passion in publishing research articles. He published 12 research papers in ScopusIndexed journals. Besides he has 33 articles to his credit which are published in various national and international journals/conferences. Apart from teaching, he held several administrative positions like, Coordinator-ED Cell, Coordinator for Patents and Copyrights, in charge Exam branch.
Published By: Blue Eyes Intelligence Engineering \& Sciences Publication (C) Copyright: All rights reserved. 